junction. ${ }^{1}$ The serum ferritin concentration in the remaining eight patients ranged from 19 to $251 \mu \mathrm{g} / \mathrm{l}$ and they had not received any abnormal amounts of blood transfusion. Large joints were not affected in these patients. Six of the 10 patients had evidence of renal osteodystrophy and underwent parathyroidectomy.

We concur with Dr N R Cary and coworkers (29 November, p 1392) that amyloid deposits are a feature of carpal tunnel syndrome in patients undergoing regular haemodialysis treatment and are related to $\beta_{2}$ microglobulin accumulation. However, we did not observe iron overload in these patients. We wonder whether the haemosiderin deposits they found in the synovial tissue of joints could result from minor haemorrhages for mechanical reasons in these susceptible patients.

R AHMAD

T HELLIWELL

F H BEDDOW

A DAVENPORT

Renal Unit,

Royal Liverpool Hospital

Liverpool L7 8XP

1 Ahmad R, AckriH P, Day JP, et al. Reversal of osteomalacia in chronic dialysis patients with heavy iron and aluminium loading. Mineral Electrolyte Metabolism 1985;11:1.

\section{Day surgery: does it add to or replace inpatient surgery?}

SIR,-To answer Dr E A Howarth's and Dr R Balarajan's question (10 January, p 133), it is self evident that if day surgery is set up as a unit in addition to the existing facilities then it will add to them. Should a day unit be set up with a calculated removal of inpatient facilities then it will replace them.

The Kingston day unit was set up in addition to existing facilities so it was bound to result in a greater total volume of work. This reflects only the huge unmet need, which is pressing at all times. Surgeons live with this every day. Although the authors say "The critical or irreducible surgical rate for a given population is not known," it would seem to many of us that we live with a basic critical level all the time. They go on to show that the New York level of provision is over twice that in England and Wales. Even if New York is overprovided by $10 \%, 20 \%$, or even $30 \%$ that still leaves us significantly underprovided, whatever the politicians may claim. We do not seek overprovision of facilities and surgeons but just ask that they be adequate

Of course we could, and should, change to treating more patients in day case units but even if these facilities are additional they will barely get us above the present disgraceful level of provision in surgery.

BRIAN HOGBIN

Brighton General Hospital,

Brighton BN2 3EW

\section{Macrocytic anaemia in patients treated with} sulphasalazine for rheumatoid arthritis

SIR,-We note that the seven patients of Dr P J Prowse and colleagues who developed macrocytosis were from a group of 50 receiving sulphasalazine for progressive erosive rheumatoid disease. The authors infer from the data presented that the development of macrocytic anaemia due to sulphasalazine therapy in this situation is therefore quite common. We do not, however, think that this conclusion is entirely justified from their data.

Of the seven cases described, four had an important potential cause of folate deficiency quite separate from sulphasalazine therapy. Thus one had malabsorption with bacterial overgrowth, a second coeliac disease, a third a "poor diet," and a fourth chronic haemolysis. In none of these patients can sulphasalazine be concluded to be the cause of macrocytosis. Of the other three patients reported, none appeared to have undergone bone marrow examination, and therefore megaloblastic anaemia was not confirmed. Also the increase in mean corpuscular volume while taking sulphasalazine was at most modest in one of the subjects (case 7). In all three cases the red cell folate value was below the lower limit of normal, but no data were given on red cell folate before sulphasalazine therapy. Modest increases in mean cell volume in the absence of folate deficiency have been reported in patients with rheumatoid arthritis taking sulphasalazine $^{1}$ and we have seen a number of cases in which a modest increase in mean cell volume occurred during sulphasalazine therapy, with a subsequent spontaneous fall and no evidence of folate deficiency or haemolysis.

The data presented are not adequate to justify a diagnosis of sulphasalazine induced folate deficiency in most of these patients. Indeed our own experience in 350 patients would suggest that this is an uncommon complication of sulphasalazine treatment in rheumatoid arthritis. The authors correctly point out that sulphasalazine need not be discontinued if anaemia occurs, but we would suggest from their data that a more reasonable conclusion would be that macrocytic anaemia occurring during sulphasalazine therapy should trigger a search for some other cause of folate deficiency.

Department of Haematology,

Royal Hallamshire Hospital,

Sheffield S10 2JF

M GREAVES

Department of Rheumatology,

Nether Edge Hospital,

Sheffield S11 9EL

1 Grindulis KA, McConkey B. Does sulphasalazine cause folate deficiency in rheumatoid arthritis? Scand f Rheum 1985;14: 265-70.

R S AMOS DEBORAH BAX

\section{The debasing of medicine in the Soviet Union}

SIR,-Dr Stewart Britten may be sincere when he says he is against $\sin$ (17 January, p 180) but unlike the Royal College of Psychiatrists he does not see it when it occurs. He insinuates that the royal college has been guilty of "coercing" the Russian people, and his intellectual gymnastics complete a $180^{\circ}$ turn by complaining that we should not fête released dissidents because this would serve as a "disincentive" in granting exit visas to other dissidents.

No doubt Dr Britten would not occupy his present post as honorary secretary of the UK/ USSR Medical Exchange Programme if he did not, on occasion, release a defensive smoke screen about the situation in the Soviet Union. Psychiatric detention as a means of political repression is a proved fact quite irrespective of whether the "patient" is mentally completely normal or whether he shows mental abnormalities: even in the latter case the decisive factor is the expression of views unacceptable to the Soviet establishment.

The views of ordinary Soviet psychiatrists are totally immaterial as far as the practice of this type of abuse is concerned. They have no voice in formulating psychiatric policies let alone policies entailing political decisions. Their vie'vs probably encompass the whole range from strong secret disapproval to uncritical acceptance of these practices. What is relevant is that we cannot meet ordinary Soviet psychiatrists unless they are chosen by the staff of the Soviet embassy in London. This was made very clear to the royal college when this question was discussed with a representative of the Soviet embassy.

I hope Mr Britten's sanguine view of better times to come is based on something more relevant than the publication of infant mortality figures. What concerns us psychiatrists and, I am sure, many other doctors is, for instance, the continued detention of Dr Anatoly Koryagin in conditions of the utmost severity in a labour camp for no reason ther than his insistence on drawing attention to the existence of psychiatric abuse as a means of political repression. His psychiatric reports on specific cases are in the possession of the Royal College of Psychiatrists and show a perversion of a humane discipline that was surpassed only by the fascist dictatorship in Germany. Dr Britten's letter would have carried at least a grain of conviction if he had, for instance, joined the royal college in its insistent demands for Dr Koryagin's immediate release.

Horton Hospital,
Epsom, Surrey KT19 8PZ

G A LOW-BEER

\section{The increase in molluscum contagiosum}

SIR,-Dr J D Oriel brings to our attention the increase in the incidence of molluscum contagiosum ( 10 January, $\mathrm{p} 74$ ). I would like to add a few points about its management.

Identification of the lesions is not as easy as it may seem, and they are often mistaken for condylomata acuminata. When a patient presents with lesions of molluscum contagiosum in a busy clinic their removal will probably be time consuming, each one needing to be removed individually.

The standard descriptions mention phenol, but this might be considered unsafe, especially if the operator's hands are unsteady. Tincture of iodine introduced into the tumour with the pointed end of a wooden stick is probably safer. ${ }^{1}$ The removal of the lesions is usually done in the outpatient department with the operator having to press on the lesion with his thumb nail, usually ungloved (in fact they are not easy to remove in gloves). There is usually some oozing of blood. In homosexuals molluscum contagiosum is often found on the face and around the natal cleft. The lesions are often worse and more widespread in individuals who are infected with the human immunodeficiency virus, ${ }^{2}$ who are often also positive for hepatitis B surface antigen. Is it not about time that physicians' standard procedures in the treatment of this condition were reconsidered?

M A WAUGH

Department of Genitourinary Medicine,

The General Infirmary,

Leeds LSI 3EX

Radcliffe-Crocker $\mathrm{H}$ Molluscum compagiosum in disease of the skin London: H K Lewis, 1903:674-82.

Farthing CF, Brown SE, Staughton RCD, Cream JJ, Mühlemann M. A Colour atlas of AIDS. London: Wolfe Medical Publications, 1986:66.

Prognosis for infants born at 23 to 28 weeks' gestation

SIR,-The question raised by Drs $C$ Skeoh and $P$ Galea (17 January, p 178) is obviously relevant in these straitened times. I must, however, confess to some unease at the recent debates concerning what amounts to selective non-treatment of extremely low birthweight infants. 